\title{
THE OMNIBUS LAW ON JOB CREATION AND PANCASILA AS THE LEGAL IDEOLOGY IN INDONESIA
}

\author{
Iwan \\ Master of Law UNISSULA \\ sip2016d.iwan@gmail.com \\ Farida \\ Master of Law UNISSULA \\ faridaruth@gmail.com \\ Fitri Pratiwi \\ Master of Law UNISSULA \\ fitripratiwi968@gmail.com \\ Zahri Aeniwati \\ Master of Law UNISSULA \\ zahriaeniwati@gmail.com \\ Siti Laelatussofah \\ Master of Law UNISSULA \\ sitilaelatussofah@gmail.com
}

\begin{abstract}
Pancasila is used as a paradigm in law in Indonesia. As a legal development paradigm, Pancasila requires that development in society be the starting point for the existence of a legal product. The purpose of this study is that to explore the value of Pancasila as a Legal Development Paradigm and its implementation in the Omnibus Law On Job Creation. This research method uses the normative method. The result of this research is that Pancasila in the prevailing statutory regulations is the Grud norm which will cover the entire contents of the Constitution. The Omnibus Law Law on job creation is intended as a law made to revoke or change several laws at once. Thus, the omnibus Law that is made is a new legal model or a new paradigm in legislation in Indonesia.
\end{abstract}

Keywords: Omnibus Law, Indonesian Legal Ideology, Pancasila, Philosophy of Law

\section{A. INTRODUCTION}

As the nation's ideology, Pancasila is a characteristic of the Indonesian nation where in its formulation there are the ideals of this country. Pancasila accommodates a difference from Sabang to Merauke, as an archipelagic country and has been recognized by the international community, the Indonesian nation consists of islands which function as a link between 
islands not the other way around as a separator. ${ }^{1}$ Automatically, Indonesia has a wide variety of regional characteristics and the number is very large. This is what caused the founders of the Indonesian nation to form this country based on Pancasila. This means that all government actions in running its government (especially in the formation of laws and regulations) must not deviate from Pancasila. A state can only be called a rule of law if the laws that are followed are good and just laws. ${ }^{2}$ This means that the law itself must be morally accountable. And that means that the law must be in accordance with the understanding of community justice and guarantee human rights.

In Indonesia, through the national legal system, which is applicable law with all its elements supporting one another in order to anticipate and overcome problems that arise in order to anticipate and anticipate problems that arise in social life, the state is based on Pancasila and the Constitution of the Republic of Indonesia. 1945. Therefore, through the Indonesian legal norms system, the prevailing legal norms are in a multi-layered and tiered system as well as in groups, where a norm applies, originates and is based on higher norms. again, and so on until the basic state norms (staatsfundamentalnorm) of the Republic of Indonesia, namely Pancasila. ${ }^{3}$

As a legal development paradigm, Pancasila requires that development in society be the starting point for the existence of a legal product. The law is directed to respond to the changing needs of society and the results contain progress and reform and improvement of the law on the problems it regulates. In carrying out the development of the national legal system, it should always refer to efforts to reform the law by eroding the remnants of Dutch colonial law products that are outdated and not in accordance with the Pancasila philosophy. The law must also be able to come forward in providing a direction for reform through the formation of laws in accordance with the mystical atmosphere of the Indonesian people in which Pancasila is used as the main spirit.

Legal development within the framework of national development must be carried out on the basis of the values that live in society. These values are the result of a joint consensus from the community which is the source and motivation in the life of the nation and state, which in the Indonesian context is called Pancasila. Therefore, philosophically the essence of Pancasila's position as a paradigm of legal development within the framework of national development contains a consequence that all aspects of legal development within the framework of national development must be based on the essence of Pancasila values. ${ }^{4}$

1 Fokky Fuad, Jumanta Hamdayama, Heri herdiawanto, Pancasila Suatu visi Kebangsaan, UAI Press, Jakarta. 2015, page. 19-20

2 Tamanahan, Brian Z, On The Rule Of Law, History, Politics, Theory, Cambridge University Press, United.Kingdom. 2004, page.91

3 Indriati, Maria Farida, I/mu Perundang-undangan, Dasar-dasar dan Pembentukannya,Kanisius, Yogyakarta. 1998, page.15

4 Fokky Fuad, Op.Cit. page.36 
Pancasila must be seen as a national guideline, as a national standard, norms and principles which also contains human rights and human responsibility. Pancasila must also be seen as a margin of appreciation as a limit or margin of appreciation for the law that lives in a pluralistic society (the living law) so that it can be justified in the life of national law. Benchmark by referring to the content of Pancasila values to form law, while still based on the values contained in the 5 (five) precepts. ${ }^{5}$

Pancasila is in a position as the Grund Norm above the UUD (Constitution). As the Grund Norm, it is this who covers the entire contents of the Constitution. Meanwhile, the constitution (UUD) is the highest source of law in the national legal order (Hierarchy of Legislative Regulations). In jurisprudence there is a well-known principle which reads: lex superior derogat legi inferiori (higher laws override lower laws). In that sense, the lower rules must not conflict with the higher rules. In the legal system there is a consequence of the existence of an order (herarchy) of laws, so that all types of laws must pay attention to the existence of legal content or norms that will be stated in a law. The law in its material content or legal norms which is based on the above laws and regulations, namely Pancasila and the 1945 Constitution. The formation of a law is based on the principle of forming a law which includes clarity of purpose, appropriate institutions or officials and conformity between types, hierarchies and content materials that can be implemented and utilized and the results for clarity of formulation in articles. Indonesia is a country of law, where the legal system is followed by civil law. Civil law countries place the constitution at the highest level in the hierarchy of laws and regulations. All civil law countries have written constitutions. Therefore, in the formation of laws and regulations, Indonesia is formed by a variety of different institutions, each of which has a function and at the same time material according to its level, so that the structure and structure, material functions in the laws and regulations form a functional relationship between one regulation and another. The formation of laws and regulations in Indonesia is based on the values of Pancasila and does not conflict with Pancasila. It shows that Pancasila is the basis and source of law in the formation of laws and regulations in Indonesia.

Pancasila is in a position as the Grund Norm above the UUD (Constitution). As the Grund Norm, it is this who covers the entire contents of the Constitution. Meanwhile, the constitution (UUD) is the highest source of law in the national legal order (Hierarchy of Legislative Regulations). In jurisprudence there is a well-known principle which reads: lex superior derogat legi inferiori (higher laws override lower laws). In that sense, the lower rules must not conflict with the higher rules. In the legal system there is a consequence of the existence of an order (herarchy) of laws, so that all types of laws must pay attention to the existence of legal content or norms that will be stated in a law. The law in its material content or legal norms which is based on the above laws and regulations, namely Pancasila and the

5 Endang Sutrisno, Bunga Rampai Hukum dan Globalisasi, Genta Press, Yogyakarta. 2007, page. 25 
1945 Constitution. The formation of a law is based on the principle of forming a law which includes clarity of purpose, appropriate institutions or officials and conformity between types, hierarchies and content materials that can be implemented and utilized and the results for clarity of formulation in articles. Indonesia is a country of law, where the legal system is followed by civil law. Civil law countries place the constitution at the highest level in the hierarchy of laws and regulations. All civil law countries have written constitutions.

Therefore, in the formation of laws and regulations, Indonesia is formed by a variety of different institutions, each of which has a function and at the same time material according to its level, so that the structure and structure, material functions in the laws and regulations form a functional relationship between one regulation and another. The formation of laws and regulations in Indonesia is based on the values of Pancasila and does not conflict with Pancasila. It shows that Pancasila is the basis and source of law in the formation of laws and regulations in Indonesia.

The Job Creation Bill has officially become Law No.11 / 2020. This law was signed by President Joko Widodo on November 2, 2020 using the concept of the Omnibus Law, which is a concept that is different from the legal model that has been used by existing laws and regulations in Indonesia. Pancasila as the basis and ideology of the state must be placed in the formation of statutory regulations. Therefore, the work creation law with the concept of the Omnibus Law is the will of the state and the will of the government. Pancasila must absolutely be confirmed in the Job Creation Law in conceptual terms and in its implementation in the formation of the legal product. Therefore in this article the author wants to explore the value of Pancasila as a Legal Development Paradigm and its implementation in the Omnibus Law on Job Creation.

\section{B. RESEARCH METHODS}

This research method uses the normative method, namely legal research which examines written law from various aspects such as aspects of theory, structure, comparison, history, philosophy, composition and the forces that bind the statutory system used, but does not use aspects of the study of its application so that research Normative juridical law is often known as theoretical legal research. This study uses an approach of historical analysis, and an approach of legal conceptual analysis.

\section{RESULT AND DISCUSSION}

\section{Pancasila as a Legal Development Paradigm.}

Pancasila as a joint consensus of all critical components of the nation has given the Indonesian nation an important and strategic meaning to continue development towards the aspired society as mandated in the 1945 Constitution. truth and statutes make Pancasila 
the way of life and foundation of the Indonesian state. All elements of the nation need not at all doubt the truth of the values of Pancasila. ${ }^{6}$

History also records how from the past until now Pancasila has often faced challenges that have resulted in crises for the existence of the Indonesian nation. The challenges faced by Pancasila as the country's view of life and foundation are always directly proportional to the challenges faced by the Republic of Indonesia as a whole. Because it has become one with the spirit of the Indonesian nation, every time there is a challenge aimed at the existence of the Indonesian nation and state, every time the existence of Pancasila is also threatened. A series of historical records is concrete evidence of how tough the challenges facing the state and Pancasila are. The formidable challenges that occurred in the past prove how Pancasila is still agreed upon as the state ideology that cannot be replaced by other ideologies. Although in the course of history Pancasila has experienced ups and downs of development, this is not due to the weakness of the values contained therein, but rather leads to inconsistency in its application. ${ }^{7}$ Therefore, the establishment of Pancasila as the basis of the state or state ideology is a compromise that is the most rational and historically capable of being a tool to unite the nation, when this nation is still in various primordial bonds.

In line with the acceptance of the truth of the noble values of Pancasila, the flow and enthusiasm for making Pancasila is a paradigm in the implementation of national development in various aspects of social, economic, political, legal, defense and security life. Pancasila is believed to play a role as a paradigm that provides basic principles as a source of motivation devoted to the national interest and the benefit of all Indonesian people. In the 1945 Constitution, it has been emphasized that the Indonesian state is a constitutional state, not a power state. The existence of Indonesia as a rule of law is marked by several main elements such as the recognition of the principles of the rule of law and the constitution, the principle of separation and limitation of power according to the constitutional system stipulated in the 1945 Constitution, the existence of the principle of a free and impartial judiciary which guarantees equality of every citizen the state in law, as well as ensuring justice for everyone, including against abuse of authority by the ruling party.

Indonesia is a state of law, where the government upholds the rule of law and is not power-oriented. Therefore, law is placed as the highest reference in the administration of the state and its government (rule of law) so that the "rule of law teaching" is adopted which places law in the highest position. Theoretically, the concept of a rule of law adopted by Indonesia does not come from a formal dimension, but in a

6 Ahmad Syafii Maarif, Islam dan Pancasila Sebagai Dasar Negara Studi tentang Perdebatan dalam Konstituante, Pustaka LP3ES Indonesia, Jakarta. 2006, page. 35

7 Sunaryo, Globalisasi Dan Pluralisme Hukum Dalam Pembangunan Sistem Hukum Pancasila, Masalah-Masalah Hukum, Jilid 42 Nomor 4, Oktober 2013 
material sense or commonly used in terms of the Welfare State or "Prosperity State".

Therefore, the goal to be achieved by the Indonesian state is the realization of a just and prosperous society both spiritually and materially based on Pancasila, so that it is also known as a rule of law with independent characteristics. Concretely, this independence is studied from the perspective of applying the concept and pattern of the rule of law in general according to the conditions of the Indonesian nation with the benchmark in the form of Pancasila. Therefore, the state of Indonesia is a constitutional state based on Pancasila. ${ }^{8}$ In other words, the rule of law of Indonesia has Indonesian characteristics. Because Pancasila is appointed as the main basis and source of law, the constitutional state of Indonesia can also be called the constitutional state of Pancasila.

Pancasila in the context of a rule of law basically has several characteristics that influence the order of life as a nation and state in Indonesia. First, Pancasila requires a harmonious relationship between the government and the people by prioritizing the principle of harmony. The principle of harmony in the constitutional state of Pancasila can be formulated in positive or negative meanings. In a positive sense, harmony means the establishment of a harmonious and harmonious relationship, while in a negative meaning it means not confrontational, not hostile to one another. With this meaning, the government in all its behavior always tries to establish a harmonious relationship with the people. Second, Pancasila guarantees freedom of religion. This shows the commitment given by the state to its citizens to implement the freedom to embrace and worship according to their religion without worrying about threats and interference from other parties. Third, Pancasila promotes the principle of kinship as a fundamental part of government administration. This strengthening of the principle of kinship provides an opportunity or opportunity for the people at large to survive in order to improve the quality of life and welfare, as long as it does not interfere with the lives of many people. Fourth, Pancasila puts forward the principle of equality in governance. Constitutionally, Article 28D of the 1945 Constitution provides a foundation to appreciate and live up to the principle of this equality in the life of the constitutional state of Pancasila, namely, among others:

a. everyone has the right to recognition, guarantee, protection and legal certainty that is just and equal treatment before the law;

b. everyone has the right to work and to receive fair and proper compensation and treatment in an employment relationship;

c. every citizen has the right to equal opportunities in government.

The enforcement of the principle of equality is a prerequisite in order to support the existence of the Pancasila rule of law to actualize or

8 Lilik Mulyadi, Pembalikan Beban Pembuktian Tindak Pidana Korupsi, Alumni, Bandung. 2007, page. 45 
implement its commitment to prospering the lives of its people as the mission of governance itself. The national development launched by the state is essentially a modernization effort in various fields of life. This condition can be interpreted as a total transformation effort from traditional life patterns to modern patterns of life in accordance with the progress of the times and is supported by science and technology. In order to achieve these development goals, the law must show its role.

According to Mochtar Kusumaatmadja, law must be able to come forward in providing direction for reform. He further said that law is a means of reforming society based on the assumption that the existence of order or order in the development or renewal effort is something that is wanted or even considered (absolutely) necessary. Both change and order (or order) are the twin goals of a developing society, so law becomes something that cannot be ignored in the development process. ${ }^{9}$

Yusuf Anwar further argued that all thoughts on law must be linked to the basic framework of national development. In a developing country like Indonesia, law is always associated with efforts to achieve a better standard of living than what has been previously achieved. The role of law is becoming increasingly important in realizing development goals. The function of law in development is not merely a means of social control (social control), but more than that, namely making efforts to move people to behave in accordance with new ways in order to achieve the state of society that they aspire to. ${ }^{10}$

The function of law as a means of community renewal means that law is used to direct people to certain patterns as desired by creating new patterns. This also means changing or even removing the old powers that are not in accordance with the times. The function of the law should be in harmony with the development of a developing society. In development, there are things that must be maintained and protected, on the other hand, the law is required to create patterns that are in accordance with development and so that changes caused by development can proceed in an orderly and orderly manner. Thus, legal development within the framework of national development must be carried out on the basis of the values that live in society. These values are the result of a joint consensus from the community which is the source and motivation in the life of the nation and state, which in the Indonesian context is called Pancasila. Therefore, philosophically, the essence of Pancasila's position as a paradigm of legal development within the framework of national development contains a consequence that all aspects of legal development within the framework of national development must be based on the essence of Pancasila values.

For this reason, Pancasila as a whole must be seen as a national guideline, as a national standard, norm and principles which also

9 Mochtar Kusumaatmadja, Konsep-Konsep Hukum Dalam Pembanguan, Kumpulan Karya Tulis, Alumni, Bandung. 2006, page.10

10 Yusuf Anwar, Pasar Modal Sebagai Sarana Pembiayaan dan Investasi, Alumni, Bandung. 2005, page.36 
contains human rights and human responsibility. Pancasila must also be seen as a margin of appreciation as a limit or margin of appreciation for the law that lives in a pluralistic society (the living law) so that it can be justified in the life of national law. Benchmark by referring to the content of Pancasila values to form law, while still based on the values contained in the 5 (five) precepts. Therefore, the implementation of legal development must be able to utilize Pancasila as a paradigm which emphasizes that development must be based on universal ethics contained in the principles of Pancasila such as:

a. Should not be contrary to the principles of the Almighty God which respects the orderliness of religious life, religious feelings and religion are of great importance.;

b. Respecting human rights values, both civil and political rights as well as economic, social and cultural rights and within the framework of relations between nations must respect the right to development ;

c. Must make national unity as the basis for appreciating the concept of "civic nationalism" which appreciates pluralism;

d. must respect the index or "core values of democracy" as a "democratic audit" tool; and

e. Must put "legal justice" in the framework of "social justice" and in the relationship between nations in the form of the principles of "global justice ". 11

Meanwhile, it must be admitted that as a former colony, there are still many legal products that are used as colonial heritage. The legal products made by the colonizers certainly contained the values of the interests of colonialism and were less and even not in accordance with the norms that lived in society. Therefore, according to Prof. Djuhaendah Hasan, reforms and the formation of national laws to replace colonial laws are absolutely necessary for the developing Indonesian society. Carrying out reforms in the development of the national legal system should continue to refer to efforts to eradicate the remnants of Dutch colonial law products that are outdated (verouder) and not in accordance with the philosophy of Pancasila and the 1945 Constitution.

This is based on the premise that every independent and sovereign country must have a national law that is both in the political and civil sector which reflects the personality of the soul and the nation's outlook on life. These considerations are basically aimed at efforts to develop national law that are continuously carried out in order to achieve the goals of the nation and state that have been mandated in the Preamble to the 1945 Constitution, where the principles of Pancasila are universal values that surround it.

Indonesia as an independent country has an interest in leaving the colonial legal system with efforts to rebuild a legal system in accordance with Pancasila values. As a paradigm that provides the basis and direction for legal development, these efforts are actually a 
formidable task because building an Indonesian legal system with the Pancasila cosmology is not only fundamentally changing the structure and legal substance of colonial legacies but including the development of a legal culture. Of course, the culture is in accordance with the spiritual structure of Indonesian society which is based on Pancasila.

As a paradigm in legal development, Pancasila requires that developments in society become the starting point for the existence of regulations. Therefore, the law is directed to respond to the changing needs of society and the results contain progress and reform and improvement of the law on the problems it governs. This process is aimed at maintaining the essential relationship between law and the needs of society in order for the law to be effective, sure, easy to find and understand by every member of society, which is of course within the framework of the Pancasila Law State.

In the current era of democratic reform, Pancasila always encourages the birth of a political reform of the law which aims to make legal reforms take place better (law reform for the better). There is a push by the dynamics of development and community needs. Therefore, it must be understood that legal reform for the better is closely related to the dynamics of community needs. Therefore. One way to do politics of legal reform is implemented through evaluation of laws and regulations (evaluatie van wetgeving). There needs to be a legal evaluation, based on legal reform for the better, the goal is that the law becomes effective. As is well known, the effectiveness of law is related to the role of law as a tool or instrument for democratic political reform goals based on the 1945 Constitution by implementing values or waarborg from the principles of the rule of law. By adopting and implementing the living law of the people, the evaluation of laws and legislation will produce a political reform of the law for the better, according to justice and human rights, equality, pluralism, and so on. is an embodiment of Pancasila values. Based on all of this, Pancasila as a paradigm provides the basis and direction in which by implementing the political reform of the law, every law or law that is irrelevant and contradicts the feelings and legal awareness of the community is renewed for the dynamics of progress in a Pancasila society.

\section{Pancasila in the Omnibus Law}

In the current era of global reform, foreign ideologies easily metamorphose in various forms and become competitors for Pancasila. Hedonism (a school that prioritizes the enjoyment of life) and various accompanying isms, for example, are increasingly becoming competitors that endanger the potentiality of Pancasila as the national personality. The intrinsic value of Pancasila is still heavily influenced by various conditional factors. In fact, a lawsuit against Pancasila as the basis of the state will automatically be a challenge to our essence and existence as humans and citizens of the Indonesian nation and state. To face both extremes (seeing the values of Pancasila as too difficult to implement by 
all Indonesians on the one hand and on the other hand seeing the values of Pancasila as less effective in fighting for the achievement of a just and prosperous society that all Indonesians desire) requires joint efforts that are not familiar. tired to live Pancasila as a noble national cultural heritage, a philosophical system that does not conflict with religious values, is normative and ideal, so that its practice is the inner demand and reason of every Indonesian. ${ }^{12}$

Pancasila as a philosophical system can be viewed from 3 (three) aspects, namely: Ontological Aspects, Epistemological Aspects and Axiological Aspects. ${ }^{13}$ From the aspect of ontology, Pancasila contains principles and values, including:

a. Almighty God is the source of universal existence. The divine ontology is religious, supernatural, transcendental and suprarational;

b. There is a universe with form and natural laws, natural resources which are the source of life for all beings: earth, sun, acid, water, fertile land, mining, and so on;

c. The existence of the human subject / person: individual, ethnic, national, human (universal);

d. The existence of a cultural order, as a manifestation of the dignity and superior personality of humans. Both national and universal culture are the embodiment of human dignity and personality: value systems, institutional systems of life such as family, society, organization, state. The existence of culture and civilization is the manifestation of human teleology: living with motivation and ideals so that it is creative, productive, ethical, virtuous;

e. The existence of a nation - a state in the form of a national system, an independent and sovereign state system, which displays national dignity, personality and dignity. An independent and sovereign state system is the pinnacle of the achievements of the nation's struggle, the center of national loyalty and pride.

Epistemological Aspects Source, process, boundary conditions, validity and nature of science. The Pancasila epistemology fundamentally includes the values and principles. The source is God, who creates the human personality with high unique dignity and potential, to live the universality, religious and divine values. The human personality as a subject is endowed with high dignity: senses, reason, taste, intention, creativity, work and conscience. The ability of human dignity is actually a gift and a divine / religious mandate. Relative human knowledge includes all four levels of existence. Science is a treasure trove and individual achievement as well as works and cultural heritage of mankind is a quality of human personality dignity. Its manifestation is the use of knowledge for human welfare, noble dignity and virtue of intellectuals (creative, patient, diligent, humble, wise). Science forms an independent

12 Luh Suryatni, Filsafat Pancasila Dan Filsafat Hukum Sebagai Dasar Rule Of Moral, Jurnal IImiah Hukum Dirgantara, Volume 6 No.2, Maret 2016, page.55-57

13 Arief Shidharta, B. ,Filsafat Hukum Pancasila, Makalah pada seminar Empat Pilar Kehidupan Berbangsa dan Bernegara, Jakarta. 2015, page.45 
and mature personality and increases personal dignity in an outward, social (social (social) attitude), psychically (patient, humble, wise) personality. Knowledge becomes a quality of personality, including passion, tenacity to create and work.

Axiological Aspects Investigate the meaning, type, level, source and nature of the universal value. The axiology of Pancasila is essentially the same as its ontology and epistemology. Almighty God as the source of value, creator of the universe and all its contents and their relationships, including the laws of nature. Moral values and laws bind humans psychologically - spiritually: reason and conscience, absolute objective according to space and time universally. Natural law and moral law constitute universal control and humanity that guarantees multiexistence for the sake of harmony and preservation of life.

The implementation of the omnibus law concept in the statutory regulations on Job creation, is more towards the Anglo-Saxon tradition which is characterized by the Common Law system. Some countries, such as America, Canada and Ireland, have used the omnibus law or omnibus bill approach. This concept is often used by the United States in making regulations. The regulation in this concept is to make a new law to amend several laws. ${ }^{14}$

The concept of the omnibus law in the Job Creation Law is a method or concept in making statutory regulations that combine several rules where the substance of the regulation is different, into a large regulation that functions as a legal umbrella. If the regulation is promulgated, it will consequently repeal several rules resulting from the merger and their substance will subsequently be declared invalid, either partially or as a whole. The government and the House of Representatives are trying to make a breakthrough in the field of law by adopting the Omnibus Law concept that has been practiced in the United States and in several other countries that adhere to the Anglo Saxon legal system.

The government together with the People's Representative Council believes that one of the advantages of the omnibus law method is that it is practical to correct many problematic regulations. Increase the speed in drafting laws, because by drafting a law with the concept of Omnibus Law while correcting laws that are no longer relevant or problematic. Law No.11 of 2020 concerning Job Creation using the concept of the Omnibus Law is a statutory regulation that is expected by the government in order to improve the progress of the nation through the field of law.

Indonesia is a state of law, where the National Law is a basic description of the national legal order, there is an assumption according

14 https://www.wartaekonomi.co.id/read260634/apa-itu-omnibus-law, (diunduh, 6 November 2020). 
to the conditions of the society concerned. ${ }^{15}$ The Job Creation Law should be able to reflect the values that exist in Pancasila, because the values of Pancasila for the Indonesian people become the basic foundation for the Indonesian nation, as well as motivation for all good deeds in everyday life and in state life. In other words, the values of Pancasila are das Sollen or ideals about goodness that must be transformed into a reality or das sein. In the life of freshness, the embodiment of the values of Pancasila must be seen in the products of the prevailing laws and regulations in Indonesia. All legal products that apply in Indonesia must be inspired by the values of Pancasila. ${ }^{16}$ In other words, all applicable laws in Indonesia must not conflict with the values of Pancasila. Therefore, Pancasila is a Grund Norm that is above the UUD (Constitution). Grund Norm is the one that covers the entire contents of the Constitution. Meanwhile, the constitution (UUD) is the highest source of law in the national legal order (Hierarchy of Legislative Regulations). In jurisprudence there is a well-known principle which reads: lex superior derogat legi inferiori (higher laws override lower laws). In that sense, the lower rules must not conflict with the higher rules. ${ }^{17}$ Where the Job Creation Law using the concept of Omnibus Law must be in accordance with the values contained in Pancasila, as the highest internalized principle in the 1945 Constitution (State Constitution). The state constitution which is conceptually (should be a necessity / obligation) is placed as the material foundation of the Law to Regional Regulations.

In the formation of laws and regulations, it must also be in accordance with the direction of legal and apparatus development in the 2005-2025 long-term development plan, namely legal and bureaucratic reform which includes legal development directed to support the realization of a sustainable economy, regulating problems related to the economy, especially the business world and industry. , as well as creating investment certainty, especially in law enforcement and protection. ${ }^{18}$ In fact, the Omnibus Law has attempted to change the legislative order, under the pretext of flexibility, efficiency and investment, has drafted the Omnibus Law on Employment Creation which greatly worries workers, from various very fundamental sides. First, the Omnibus Law on Job Creation has overhauled the manpower system, which was originally in accordance with Law Number 13 of 2003 concerning Manpower, which regulates industrial relations through tripartite, by involving the District Government, as the organizer of manpower as mandated by the 1945 Constitution article 18 paragraph 5,

15 Junaedi, Pancasila Sebagai Sistem Filsafat Dalam Penerapan Konsep Negara Hukum Indonesia, Syntax Literate : Jurnal IImiah Indonesia, Vol. 3, No.12 Desember 2018, page.102-103

16 Ibid.,

17 Suko Prayitno, Mekanisme Pembatalan Peraturan Daerah Dan Akibat Hukumnya Berdasarkan Asas Lex Superiori Derogat Legi Inferiori, Jurnal Surya Kencana Satu : Dinamika Masalah Hukum dan Keadilan, Vol. 8 No. 2, Oktober 2017, page. 114

18 Arba, Hukum Tata Ruang dan Tata Guna Tanah (Prinsip-prinsip Hukum Perencanaan Penataan dan Penatagunaaan Tanah, Sinar Grafika, Jakarta,2019, page.5 
where the government regions through the Manpower Office legalize Workers' Unions, build Tripartite Industrial relations, both in disputes of interest, as well as discussion of MSE issues as a social safety net in the labor sector.

However, ironically, the passage of the Omnibus Law on Job Creation has eliminated this system. Thus, the Omnibus Law on Cipta Kerja has destroyed the order of the Indonesian labor system, by eliminating the role of the State in the field of Manpower (Regency as the lower constitutional hierarchy of the State) and the mandate of the 1945 Constitution Article 18. Amendments to the Omnibus Law on Job Creation, which take away rights Workers and threatening workers' welfare, namely eliminating tripartite, UMK, freedom of association, threat of layoffs at any time (paralyzed worker democracy), because of the case of union busting, will always lead to layoffs if the dispute does not meet an agreement, thus if the determination of Wages is carried out in a company with Bipartite, which legalizes workers dismissal freely, what exists is an unbalanced negotiation, reduced severance pay, and confusion over the law.

In addition, the Omnibus Law Law is also incompatible with the Regional Autonomy Law, which gives flexibility to regions to manage the manpower sector. With the loss of workers' political democracy in industrial relations, in fact the government and the DPR RI have made a law that has the potential to be incompatible with the second and fifth precepts. Second, on the pretext of accelerating investment activities, which pursue economic growth, the Omnibus Law on Job Creation, is allegedly more pro-investors (both National and Multi-National), rather than paying attention to Worker Welfare, which has an impact on increasing purchasing power, and the welfare of National workers. , thus Industrial activities initiated through the Omnibus law, have lost the substance of industrial activities, which are expected to have a straight correlation to the welfare of the Indonesian people, whether involved directly or indirectly in Industrialization activities. The availability of business activities is to increase the purchasing power of the Indonesian people, not just economic growth, which has the potential not to be directly proportional to the increase in purchasing power.

The National Economy is organized based on economic democracy with the principles of togetherness, equitable efficiency, sustainability, environmental insight, independence, and by maintaining a balance between progress and national economic unity. it is clear that the economy that the State intends to establish in accordance with the constitution is the development of national economic democracy, while the Omnibus Law on Job Creation is currently legalized, in fact it wants to legalize millennial imperialism, by facilitating the flow of investment and foreign workers doing business in Indonesia, with a statutory regulation that wants to reduce the wages of "Indonesian workers" by cutting various social security guarantees for labor, this is of course not in accordance with Article 27 paragraph 2 of the 1945 Constitution, 
which reads "every citizen has the right to work and livelihood feasible for humanity "so that with the Omnibus Law on Job Creation, foreign investors will not only facilitate the investment method, but also facilitate the means of making profits in Indonesia, including from the labor sector, besides that foreign workers have been facilitated systematically, so that the National manpower protection is almost lost. .

Third, the Omnibus Law on Job Creation, indicates that the future of Indonesian Manpower, on the economic side and political sovereignty, is of great concern, because from an economic point of view, and the power of workers inside or outside the company in the space of Industrial relations is in a very vulnerable position. Where this can be seen from the wage formula pattern that eliminates the inflation item, which every year, throughout history, has always increased quite significantly, thus the employee's financial position will experience depreciation each year due to inflation and the Rupiah exchange rate, in PP No. 78/2015 which is considered a severe wage system, because it does not consider the Rupiah exchange rate, it is further exacerbated by the wage pattern of the Job Creation Law Onibus Law system.

Fourth, the Omnibus Law on Employment Creation, apparently perpetuates the Outsorcing and Contract Work system, even though workers in Indonesia expect that their work status will be clarified as permanent workers or PKWTT, as a result of dedication, loyalty during productive periods, until retirement. This is very fundamental, in the Industrial relations system which is planned through the Omnibus Law, because the result of this law will have an impact on the loss of the democratic climate in the field of Manpower, namely One Economic Democracy, democratic rights that have a systemic impact on the workers' economy. , starting to be paralyzed, on the other hand, the welfare of workers will be able to move the real sector, this is what causes economic growth to be a positive factor in the global economic system, but this does not appear in the Omnibus Law, because economic growth was initiated through the omnibus Law on Job Creation, in fact, it will devastate the real sector, because workers' income has been depreciated from time to time.

Fifth, the Omnibus Law Law can injure workers 'political democracy, threaten workers' freedom of association both inside and outside the company, thus the omnibus Law is actually not in accordance with the Indonesian spirit, this picture we can understand is indeed a natural thing if various parties are inflamed related to the Omnibus Law on Employment Creation, which does not show any benefits and benefits for current and future workers.

\section{CONCLUSION}

Pancasila in the prevailing statutory regulations is the Grud norm which will cover the entire contents of the Constitution. As a legal development paradigm, Pancasila requires that development in society be the starting point for the existence of a legal product. The law is directed to 
respond to the changing needs of society and the results contain progress and reform and improvement of the law on the problems it regulates. Therefore, the development of the national legal system should continue to refer to legal reform efforts. Pancasila is a source of law as stated in the constitution (UUD) as the highest source of law of the national legal order (Hierarchy of Legislative Regulations).

In jurisprudence there is a well-known principle which reads: lex superior derogat legi inferiori (higher laws override lower laws). In that sense, the lower rules must not conflict with the higher rules. Where the Job Creation Law using the concept of Omnibus Law must be in accordance with the values contained in Pancasila, as the highest internalized principle in the 1945 Constitution (State Constitution). Ancasila values are the philosophy (view of life) of the Indonesian nation, so that they become the national identity which is believed to be a source of values for truth, goodness, justice and wisdom in the life of society, nation and state. Thus, how the values in Pancasila must be contained in the work creation Omnibus Law. The Omnibus Law Law on job creation is intended as a law made to revoke or change several laws at once. Thus, the omnibus Law that is made is a new legal model or a new paradigm in legislation in Indonesia. Due to a new paradigm in laws and regulations in Indonesia, the Omnibus Law law that is made will change the system of legislation, because the concepts and theories are different from the legal model that has been applicable in Indonesia.

\section{BIBLIOGRAPHY}

\section{Book:}

Arba, 2019, Hukum Tata Ruang dan Tata Guna Tanah (Prinsip-prinsip Hukum Perencanaan Penataan dan Penatagunaaan Tanah, Sinar Grafika, Jakarta;

Ahmad Syafii Maarif, 2006, Islam dan Pancasila Sebagai Dasar Negara Studi tentang Perdebatan dalam Konstituante, Pustaka LP3ES Indonesia, Jakarta;

Endang Sutrisno, 2007, Bunga Rampai Hukum dan Globalisasi, Genta Press, Yogyakarta;

Fokky Fuad, Jumanta Hamdayama, Heri herdiawanto, 2015, Pancasila Suatu visi Kebangsaan, UAI Press, Jakarta;

Indriati, Maria Farida, 1998, IImu Perundang-undangan, Dasar-dasar dan Pembentukannya, Kanisius, Yogyakarta;

Lilik Mulyadi, 2007, Pembalikan Beban Pembuktian Tindak Pidana Korupsi, Alumni, Bandung;

Mochtar Kusumaatmadja, 2006, Konsep-Konsep Hukum Dalam Pembanguan, Kumpulan Karya Tulis ,Alumni, Bandung; 
Tamanahan, Brian Z, 2004, On The Rule Of Law, History, Politics, Theory, Cambridge University Press, United.Kingdom;

Sunaryo, Globalisasi Dan Pluralisme Hukum Dalam Pembangunan Sistem Hukum Pancasila, Masalah-Masalah Hukum, Jilid 42 Nomor 4, Oktober 2013;

Yusuf Anwar, 2005, Pasar Modal Sebagai Sarana Pembiayaan dan Investasi, Alumni, Bandung;

\section{Journal:}

Arief Shidharta, Filsafat Hukum Pancasila, Makalah pada seminar Empat Pilar Kehidupan Berbangsa dan Bernegara, Jakarta, 2015;

Luh Suryatni, Filsafat Pancasila Dan Filsafat Hukum Sebagai Dasar Rule Of Moral, Jurnal IImiah Hukum Dirgantara, Volume 6 No.2, Maret 2016;

Junaedi, Pancasila Sebagai Sistem Filsafat Dalam Penerapan Konsep Negara Hukum Indonesia, Syntax Literate : Jurnal IImiah Indonesia, Vol. 3, No.12 Desember 2018;

Suko Prayitno, Mekanisme Pembatalan Peraturan Daerah Dan Akibat Hukumnya Berdasarkan Asas Lex Superiori Derogat Legi Inferiori, Jurnal Surya Kencana Satu : Dinamika Masalah Hukum dan Keadilan, Vol. 8 No. 2, Oktober 2017;

\section{Website:}

https://www.wartaekonomi.co.id/read260634/apa-itu-omnibus-law, (diunduh, 6 November 2020; 